Outlining the complex interaction between the two phenomena

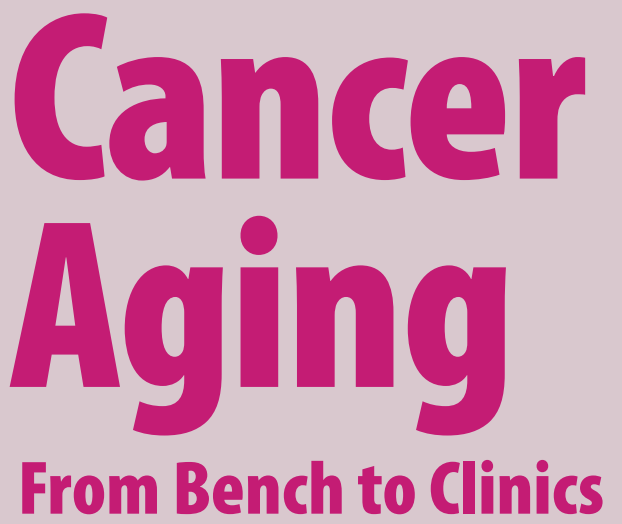

Editor

Martine Extermann

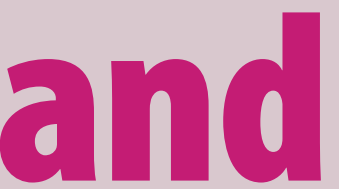

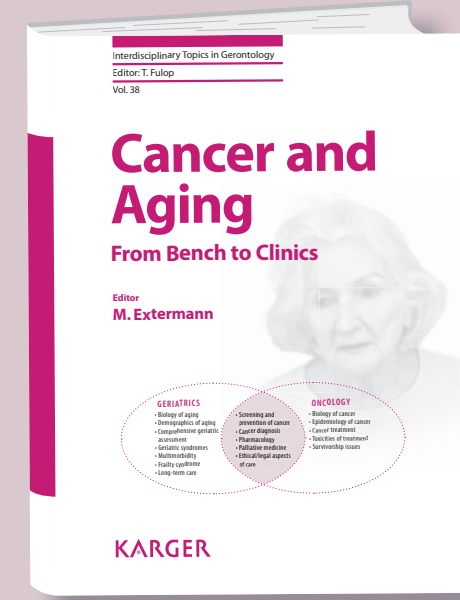

Cancer is clearly an age-related disease. Recent research in both aging and cancer has demonstrated the complex interaction between the two phenomena. This affects a wide spectrum of research and practice, anywhere from basic research to health care organization.

Core examples of these close associations are addressed in this book. Starting with basic research, the first chapters cover cancer development, mTOR inhibition, senescent cells altering the tumor microenvironment, and immune senescence affecting cancer vaccine response. Taking into account the multidisciplinarity of geriatric oncology, several chapters focus on geriatric and oncologic aspects in patient assessment, treatment options, nursing and exercise programs. The book is rounded off by a discussion on the impact of the metabolic syndrome illustrating the interactions between comorbidity and cancer and a chapter on frailty.

This book provides the reader with insights that will hopefully foster his or her reflection in their own research and practice to further the development of this most exciting field. Given the aging of the population worldwide and the high prevalence of cancer, it is essential reading not only for oncologists and geriatricians but for all health practitioners.

Interdisciplinary Topics in Gerontology, vol. 38

\section{Cancer and Aging}

\section{From Bench to Clinics}

Editor: Extermann, M. (Tampa, Fla.) VIII + 170 p., 8 fig., 2 in color, 13 tab., 2013 CHF 163.- / EUR 136.- / USD 192.00 (hard cover) CHF 196.- / EUR 163.- / USD 230.00 (online) Online versions for institutional purchase Prices subject to change EUR price for Germany, USD price for USA only ISBN 978-3-318-02306-0 (hard cover) e-ISBN 978-3-318-02307-7
Fields of Interest: Gerontology/Geriatrics; Oncology; Immunology, Metabolic Diseases, Hospital Care, Public Health

\section{www.karger.com/itoge}

\section{CONTENTS}

Preface: Extermann, $M$.

Chronic Mechanistic Target of Rapamycin Inhibition: Preventing Cancer to Delay Aging, or Vice Versa?: Sharp, Z.D.; Curiel, T.J.; Livi, C.B.

Senescent Cells and Their Secretory Phenotype as Targets for Cancer Therapy:

Velarde, M.C.; Demaria, M.; Campisi, J.

Cancer Vaccination at Older Age: Gravekamp, C.

Immunology of Aging and Cancer

Development: Fulop, T.; Larbi, A.; Kotb, R.; Pawelec, G.

Metabolic Syndrome and Cancer: From Bedside to Bench and Back: Extermann, M.

Frailty: A Common Pathway in Aging and

Cancer: Balducci, L.

Targeting Age-Related Changes in the Biology of Acute Myeloid Leukemia: Is the Patient Seeing the Progress?: Vey, N.

Comprehensive Geriatric Assessment in

Oncology: Mohile, S.G.; Magnuson, A.

Pharmacology of Aging and Cancer: How Useful Are Pharmacokinetic Tests?:

Lichtman, S.M.

Surgery in Older Cancer Patients - Recent Results and New Techniques: Worth the Investment?: van Leeuwen, B.L.; Huisman, M.G.; Audisio, R.A.

Organizing the Geriatrician/Oncologist Partnership: One Size Fits All? Practical

Solutions: Holmes, H.M.; Albrand, G.

Geriatric Oncology Nursing: Beyond Standard

Care: Overcash, J.

Exercise for Older Cancer Patients: Feasible and Helpful?: Klepin, H.D.; Mohile, S.G.; Mihalko, S.

Aging and Cancer - Addressing a Nation's

Challenge: Bréchot, J.-M.; Le Quellec-Nathan, M.; Buzyn, $A$.

Author Index Subject Index 
Please send:

copy/ies: Vol. 38: Cancer and Aging

CHF 163.- / EUR 136.- / USD 192.00 (hard cover) ISBN 978-3-318-02306-0

copy/ies: Vol. 37: Body Composition and Aging CHF 188.- / EUR 157.- / USD 221.00 (hard cover) ISBN 978-3-8055-9521-6

copy/ies: Vol. 36: Primate Reproductive Aging CHF 196.- / EUR 163.- / USD 231.00 (hard cover) ISBN 978-3-8055-8522-4

copy/ies: Vol. 35: Mechanisms of Dietary Restriction in Aging and Disease CHF 188.- / EUR 157.- / USD 221.00 (hard cover) ISBN 978-3-8055-8170-7

\section{the book series}

Interdisciplinary Topics in Gerontology on continuation beginning with vol.

All Karger series are available on continuation. Each new title will be sent upon publication until order is countermanded.

For easy ordering or further information about the series log on to: www.karger.com

Postage and handling free with prepayment

Payment

Please charge this order to my credit card

\begin{tabular}{|l|l|}
\hline American Express & Diners \\
\hline Visa & Mastercard \\
\hline
\end{tabular}

\section{Card No:}

Exp. date:

CVV/CVC

\begin{tabular}{|c|}
\hline Check enclosed \\
\hline
\end{tabular}

Name/Address (please print):

\section{E-Mail:}

Date:

Signature:

Orders can be placed at agencies, bookstores, directly with the publisher, or with any Karger distributor.

S. Karger AG, P.0. Box, 4009 Basel (Switzerland) Fax +4161306 12 34, E-Mail orders@karger.com USA: S. Karger Publishers, Inc., 26 West Avon Road, P.0. Box 529, Unionville, CT 06085 (USA), Toll free: +1-800-828-5479

Germany: S. Karger GmbH, 79095 Freiburg

France: Librairie Médi-Sciences, 75007 Paris

Japan: Karger Japan, Inc., Tokyo 105-0012

South East Asia, China and Taiwan: Karger Regional Office, Kuala Lumpur 50470 (Malaysia)

For details and further representatives and agencies see www.karger.com/worldwide

\section{Interdisciplinary Topics in Gerontology}

Editors

Tamas Fulop, Sherbrooke, Que. ISSN 0074-1132/e-ISSN 1662-3800

At a time when interest in the process of aging is driving more and more research, Interdisciplinary Topics in Gerontology offers investigators a way to stay at the forefront of developments. This series represents a comprehensive and integrated approach to the problems of aging and presents pertinent data from studies in animal and human gerontology. In order to provide a forum for a unified concept of gerontology, both the biological foundations and the clinical and sociological consequences of aging in humans are presented. Individual volumes are characterized by a synthetic view of the aging process, novel ideas, and original approaches to healthy aging as well as agerelated functional decline.
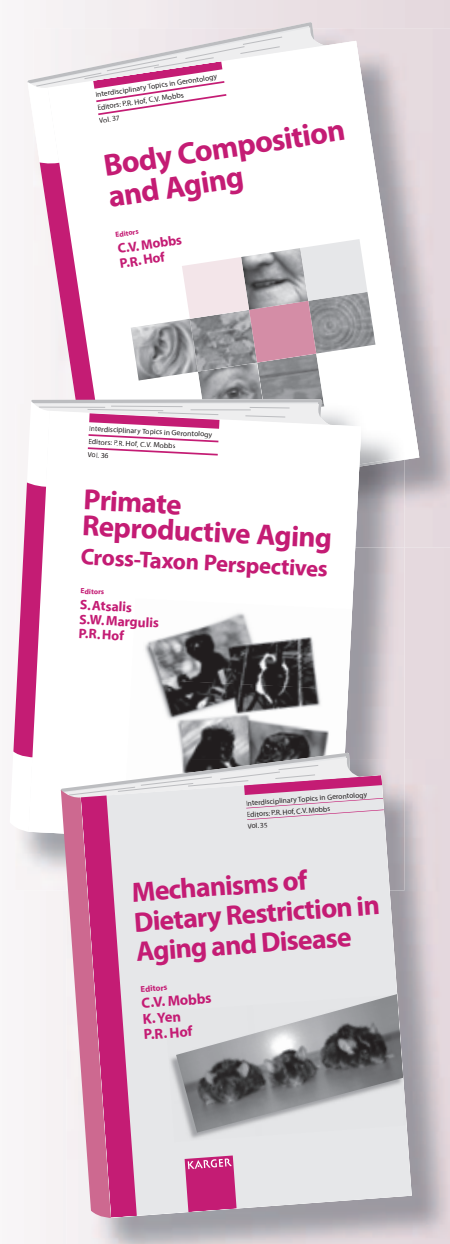

Vol.37

Body Composition and Aging

Editors: Mobbs, C.V.; Hof, P.R. (New York, N.Y.)

VIII + 208 p., 25 fig., 1 tab., 7 tab., 2010 CHF 188.- / EUR 157.- / USD 221.00 (hard cover) CHF 226- / EUR 188. - / USD 265.00 (online) ISBN 978-3-8055-9521-6 (hard cover) e-ISBN 978-3-8055-9522-3

Vol. 36

\section{Primate Reproductive Aging}

Editors: Atsalis, S., Margulis, S.W. (Chicago, III.); Hof, P.R. (New York, N.Y.)

VIII + 200 p., 53 fig., 15 tab., 2008

CHF 196. - / EUR 163.- / USD 231.00 (hard cover) CHF 235. - / EUR 196.- / USD 277.00 (online) ISBN 978-3-8055-8522-4 (hard cover) e-ISBN 978-8055-8523-1

Vol. 35

Mechanisms of Dietary Restriction in Aging and Disease

Editors: Mobbs, C.V.; Yen, K.; Hof, P.R. (New York, N.Y.)

VIII + 198 p., 23 fig., 5 tab., 2007

CHF 188. - EUR 157.- / USD 221.00 (hard cover)

CHF 226. - / EUR 188.- / USD 265.00 (online)

ISBN 978-3-8055-8170-7 (hard cover)

e-ISBN 978-3-318-01390-0

Online versions for institutional purchase

Prices subject to change

EUR price for Germany,

USD price for USA only

Vol. 1-34 are available. Please ask for details

www.karger.com/itoge

\section{KARGER}

